\title{
FOUR CLINICAL VARIANTS OF CONGENITAL ADRENAL HYPERPLASIA
}

\author{
BY \\ W. HAMILTON and M. G. BRUSH \\ From the University Department of Child Health and the Royal Hospital for Sick Children, Glasgow, \\ and the University Department of Steroid Biochemistry and the Royal Infirmary, Glasgow
}

(RECEIVED FOR PUBLICATION AUGUST 26, 1963)

Three clinical types of congenital adrenogenital virilism due to adrenal hyperplasia have now been well defined. These are simple virilization, virilization with excessive sodium loss and danger to life and virilization combined with hypertension. Clinical subvariants have also been described in association with hypoglycaemia (White and Sutton, 1951; Wilkins, Crigler, Silverman, Gardner and Migeon, 1952), with periodic fever (Gonzales and Gardner, 1956; Gardner and Migeon, 1959) and with the late onset of sodium loss (Cara and Gardner, 1960). More recently Bongiovanni (1962) has described a variant that, when occurring in males, is characterized by incomplete masculinization, hypospadias and usually severe sodium loss, although in females it leads to the familiar virilism.

The treatment of congenital adrenal hyperplasia has been much simplified since Wilkins, Lewis, Klein and Rosemberg (1950) showed that cortisone decreased the urinary 17-oxosteroids. Deoxycorticosterone acetate (D.C.A.) in conjunction with cortisone and increased dietary salt usually control sodium loss. However, some cases have proved to be resistant to cortisone, though not to the newer steroid analogues, while others have failed to respond to seemingly adequate steroid replacement.

The adrenocortical enzyme defects underlying the principal types of adrenogenital virilism have been extensively investigated and the subject has been reviewed recently (Bongiovanni and Eberlein, 1961). However, the occurrence of further clinical subvariants indicates the need for separate clinical and biochemical elucidation of each case as a guide to adequate or optimum treatment. The following four cases serve to emphasize these facts. As far as is known, Case 4 is the first of its kind to be described in this country.

\section{Case Reports}

Case 1. This child, born January 27, 1954, was of ambiguous sex having a curved phallus with an opening at the tip. Both this and another opening on the perineum admitted a probe to a depth of $1 \mathrm{~cm}$. The scrotum was bifid and the testes were not palpated.

When 5 weeks of age, a skin biopsy and buccal smear examined for sex chromatin indicated that the child was female. The urinary 17-oxosteroids were reported as $0.4 \mathrm{mg}$. per day. When 2 years of age the perineum was opened up in the midline and the urethral and vaginal orifices were found to open on to a small vestibule. The incision was sutured to leave the vestibule open and on healing the perineum looked remarkably normal for a female child.

During the following four years, the only feature noted was progressive clitoral enlargement. When the girl was $6 \frac{1}{2}$ years of age, the clitoris was amputated, and at laparotomy, normal ovaries, tubes and uterus were seen. Histological examination of material from the gonads showed only ovarian tissue with normal primordial follicles and some cystic follicles. The clitoris continued to enlarge. Pubic hair and breast development appeared.

She was admitted to the Royal Hospital for Sick Children, Glasgow, on November 12, 1962, for further investigation. She was then 8 years 10 months. Her height was $137 \mathrm{~cm}$. (average $126 \mathrm{~cm}$.) and she weighed $29.5 \mathrm{~kg}$. (average $25 \mathrm{~kg}$.). Apart from an enlarged clitoris and pubic hair (Fig. 1) she was a healthy girl. There was no history of vaginal bleeding. Bone radiography showed a normal bone age. A high urinary excretion of steroid metabolites (Table 1) was found, while the daily oestrogen levels were: oestrone $2 \cdot 3 \mu \mathrm{g}$., oestradiol $1 \cdot 1 \mu \mathrm{g}$.; oestriol $1.9 \mu \mathrm{g}$. (These values are within normal range for age of patient.)

It was decided at this time to suppress adrenocortical function with prednisolone ( $\Delta^{1}$-hydrocortisone) $10 \mathrm{mg}$. daily.

Summary. A 9-year-old female pseudohermaphrodite with adrenocortical hyperplasia was treated first by excision of the clitoris and then by replacement therapy. At present she is having prednisolone $5 \mathrm{mg}$. daily. 


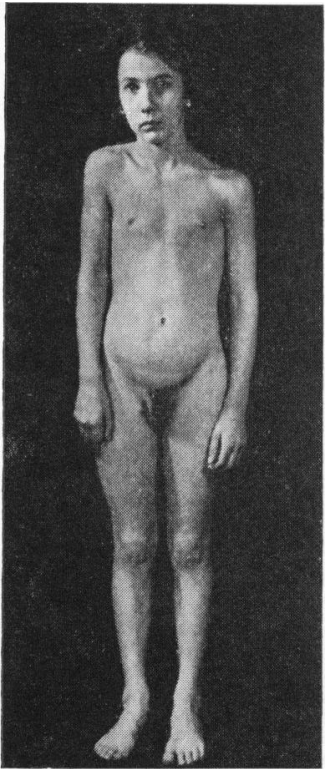

FIG. 1.-Case 1, age 9 years. Regrowth of clitoris after amputation arrested by prednisolone administration.

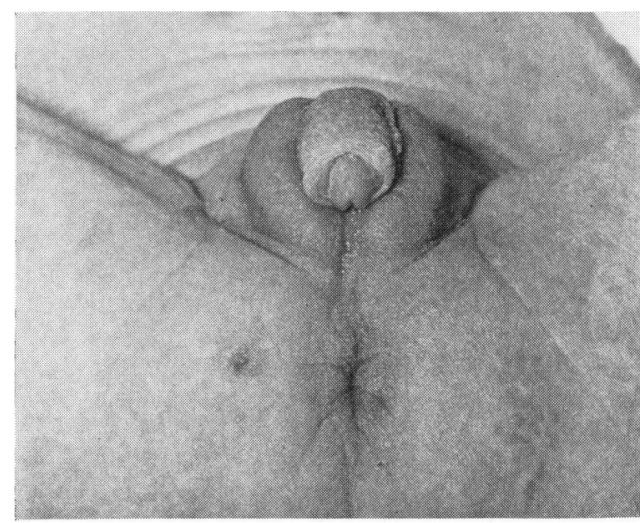

FIG. 2.-Ambiguous genitalia of Case 2.

Case 2. She was born on May 16, 1954, admitted to the Royal Hospital for Sick Children, Glasgow, at 2 weeks in acute adrenal failure. The genitalia are shown in Fig. 2. Diagnosis, immediate treatment and early management have previously been reported (Coleman and Arneil, 1958). Substitution therapy was with cortisone $25 \mathrm{mg}$. thrice daily, deoxycorticosterone acetate (D.C.A.) $200 \mathrm{mg}$. implants at 6-month intervals

TABLE 1

URINARY STEROID OUTPUT (mg./24 hours)

\begin{tabular}{|c|c|c|c|c|c|c|c|c|c|c|c|c|c|c|}
\hline \multirow[b]{2}{*}{$\begin{array}{l}\text { Case } \\
\text { No. }\end{array}$} & \multirow[b]{2}{*}{ Age } & \multicolumn{6}{|c|}{ Before Treatment } & \multicolumn{7}{|c|}{ After Treatment } \\
\hline & & $17-\mathrm{OS}$ & 17-OGS & 17-OHCS & $\begin{array}{l}\text { 21-deoxy- } \\
\text { ketols }\end{array}$ & P'triol & $\mathbf{R}$ & $\begin{array}{l}\text { Drug and } \\
\text { Dosage } \\
\text { (mg./day) }\end{array}$ & $17-\mathrm{OS}$ & 17-OGS & 17-OHCS & $\begin{array}{l}\text { 21-deoxy- } \\
\text { ketols }\end{array}$ & P'triol & $\mathbf{R}$ \\
\hline 1 & 9 yrs. & $6 \cdot 9$ & $5 \cdot 6$ & $10 \cdot 3$ & $4 \cdot 7$ & $30^{*}$ & & $\Delta_{10}^{1-\mathrm{F}}$ & $2 \cdot 1$ & $1 \cdot 5$ & $2 \cdot 9$ & $1 \cdot 4$ & & \\
\hline 2 & $\begin{array}{l}3 \mathrm{yrs} . \\
7 \mathrm{yrs} .\end{array}$ & $4 \cdot 0$ & & & & 48 & & $\begin{array}{c}\Delta^{1}-\mathrm{F} \\
5 \\
\mathrm{DX} \\
6 \\
\mathrm{DX} \\
4 \\
\mathrm{DX} \\
1 \\
9 \alpha \mathrm{F} \\
0 \cdot 4\end{array}$ & $\begin{array}{l}2 \cdot 5 \\
6 \cdot 9 \\
4 \cdot 3 \\
1 \cdot 3\end{array}$ & & & & $\begin{array}{l}1 \cdot 6 \\
0.8 \\
0.7 \\
0.13\end{array}$ & \\
\hline 3 & $\begin{array}{l}15 \text { mths. } \\
21 \text { mths. } \\
26 \text { mths. } \\
42 \text { mths. }\end{array}$ & 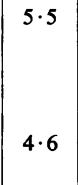 & $6 \cdot 0$ & 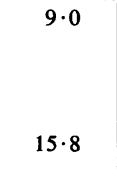 & $3 \cdot 0$ & $1 \cdot 9$ & \begin{tabular}{l|}
2 \\
$0 \cdot 8$ \\
$1 \cdot 4$ \\
$2 \cdot 3$
\end{tabular} & $\begin{array}{c}\mathrm{E} \\
50 \\
\mathrm{E} \\
25 \\
\mathrm{E} \\
50 \\
\mathrm{DX} \\
2\end{array}$ & $1 \cdot 3$ & $\begin{array}{r}2 \cdot 4 \\
4 \cdot 7 \\
14 \cdot 7 \\
0 \cdot 8\end{array}$ & $\begin{array}{l}10 \\
8 \cdot 4 \\
35 \cdot 7 \\
2 \cdot 1\end{array}$ & $\begin{array}{r}7 \cdot 6 \\
3 \cdot 1 \\
21 \cdot 0 \\
1 \cdot 3\end{array}$ & $\begin{array}{l}1.0 \\
0.9\end{array}$ & $0 \cdot 12$ \\
\hline 4 & $\begin{array}{c}\text { Birth } \\
2 \text { days } \\
3 \text { days } \\
6 \text { days } \\
7 \text { days } \\
20 \text { days }\end{array}$ & $\begin{array}{l}4 \cdot 8 \\
4 \cdot 3\end{array}$ & $\begin{array}{l}2 \cdot 9 \\
3 \cdot 1\end{array}$ & $\begin{array}{l}6 \cdot 5 \\
5 \cdot 2\end{array}$ & $\begin{array}{l}3 \cdot 6 \\
2 \cdot 1\end{array}$ & $\begin{array}{l}0.048 \\
0.028 \\
0.049\end{array}$ & & $\begin{array}{c}\mathbf{E} \\
20\end{array}$ & $1 \cdot 8$ & $8 \cdot 4$ & $11 \cdot 3$ & $2 \cdot 9$ & $1 \cdot 8$ & \\
\hline
\end{tabular}

P'triol, pregnanetriol; R, 11 deoxy/11-oxygenated-17-oxosteroids.

$\Delta^{1}-\mathrm{F}$, prednisolone; DX, dexamethasone; E, cortisone; $9 \alpha \mathrm{F}, 9-\alpha$-fluorohydrocortisone.

* Overestimate due to presence of non-specific chromogens. 
and extra dietary salt. By 2 years of age she had acquired a voracious appetite for salt and was taking 20-25 g. daily. This was associated with considerable thirst and polyuria, but further D.C.A. was not given. At 3 years of age, prednisolone $20 \mathrm{mg}$. daily was given to replace cortisone, since the urinary excretion of 17-oxosteroids was then 3-4 mg. per day. Salt addiction persisted, but there was no further virilization. When $4 \frac{1}{2}$ years old her bone age was equivalent to $1 \frac{1}{2}$ years and because of this, prednisolone was gradually reduced to $5 \mathrm{mg}$. daily. During the following year she had two adrenal crises, precipitated by mild respiratory infections. These were readily controlled and on each occasion D.C.A. implants of $100 \mathrm{mg}$. were made.

She was admitted when 7 years old (1962) for adrenal and gynaecological assessment. She was then $108 \mathrm{~cm}$. (average $118.4 \mathrm{~cm}$.) and weighed $20.5 \mathrm{~kg}$. (average $22 \cdot 1 \mathrm{~kg}$.). To obtain baseline urinary levels, prednisolone was withdrawn but salt was allowed. Inadvertently, extra salt was omitted from the diet and within 48 hours a salt-losing crisis ensued. At this period urinary pregnanetriol was found to be at the high level of $48 \mathrm{mg}$. per day, using the method of Fotherby and Love (1960). To exclude the presence of non-specific chromogens estimating as pregnanetriol, the analysis was checked by the procedure of Cox (1959) and was found to be correct.

Dexamethasone (9- $\alpha$-fluoro-16- $\alpha$-methylprednisolone) $6 \mathrm{mg}$. daily and salt $20 \mathrm{~g}$. daily were given with immediate good effect. Over 21 days dexamethasone was reduced to $1 \mathrm{mg}$. daily, but the high salt intake continued. It will be seen from Table 1 that urinary pregnanetriol excretion rapidly fell to normal levels with the commencement of suitable steroid therapy. She continued on this régime for two months and became extremely moon-faced and obese, although without hirsutism or hypertension.

In an attempt to control the polyuria and polydipsia induced by her large appetite for salt, it was decided to replace dexamethasone with 9 - $\alpha$-fluorohydrocortisone. The dosage of this drug was increased gradually from $0.1 \mathrm{mg}$. to $0.4 \mathrm{mg}$. daily, when the child abruptly stopped eating salt and took food without added salt. Polyuria and polydipsia ceased; her blood pressure remained about 100/70 mm. Hg. Pregnanetriol excretion was then $125 \mu \mathrm{g}$. per day (Table 1).

Summary. A 7-year-old female pseudohermaphrodite with adrenocortical hyperplasia accompanied by excessive sodium loss, was first treated with cortisone, D.C.A. and extra dietary salt and later with prednisolone and extra salt. At present she is well controlled on $9-\alpha-$ fluorohydrocortisone $0.45 \mathrm{mg}$. daily without extra salt. She has grown $6 \mathrm{~cm}$. in eight months and has lost the Cushing-type appearance.

Case 3. This male child was born on July 8, 1958, and was the fourth child of a full cousin marriage. The neonatal period was uneventful. He grew rapidly and when he was 1 year and 3 months his parents observed early pubic hair and penile enlargement (Fig. 3). Clinical examination at this time showed a child, tall for his age, muscular and with slight breast enlargement. Bone age was 4 years. Blood pressure was normal. Urinary excretion of 17-oxosteroids was $5.5 \mathrm{mg}$. per day. He was given cortisone $50 \mathrm{mg}$. daily for one month and thereafter $25 \mathrm{mg}$. daily. 17-oxosteroid output was then $1.3 \mathrm{mg}$. per day.

When seen six months later, growth had proceeded unchecked. His weight age was $4 \frac{1}{2}$ years, height age $2 \frac{1}{2}$ years and bone age 6 years. Urinary steroid excretion was again raised (Table 1). Cortisone was increased to $75 \mathrm{mg}$. daily. His parents alleged that this high dosage was maintained till he was next seen at 3 years of age. His bone age was then equivalent to 10 years. Under strict in-patient supervision cortisone was increased over six months to $300 \mathrm{mg}$. daily. Nevertheless, his bone age continued to advance to 11 years. Cortisone was then withdrawn abruptly without obvious ill effects. He was then given dexamethasone $2 \mathrm{mg}$. daily plus cortisone $50 \mathrm{mg}$. daily.

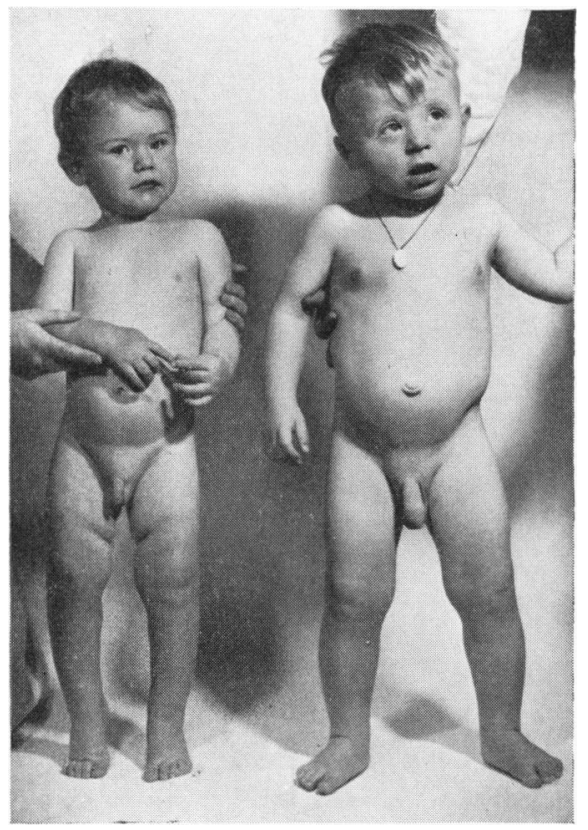

Fig. 3.-Case 3, aged 1 year 3 months.

Special Investigations. Skull radiographs showed a normal pituitary fossa. Intravenous pyelogram and presacral gas insufflation of the retroperitoneum revealed kidneys and adrenal glands normal in size, shape and position. Blood corticotrophin was $5 \cdot 71$ milli units per $100 \mathrm{ml}$. whole blood (mean normal adult value 0. 71 m.u. per $100 \mathrm{ml}$. blood). It will be seen from Fig. 4 that the adrenal glands were suppressed by corticosterone and dexamethasone. He was therefore maintained on dexamethasone $2 \mathrm{mg}$. daily and cortisone $50 \mathrm{mg}$. daily.

Summary. A male with pubertas praecox and advanced ossification due to adrenocortical hyperplasia. Cortisone in daily doses of $300 \mathrm{mg}$. did not suppress 


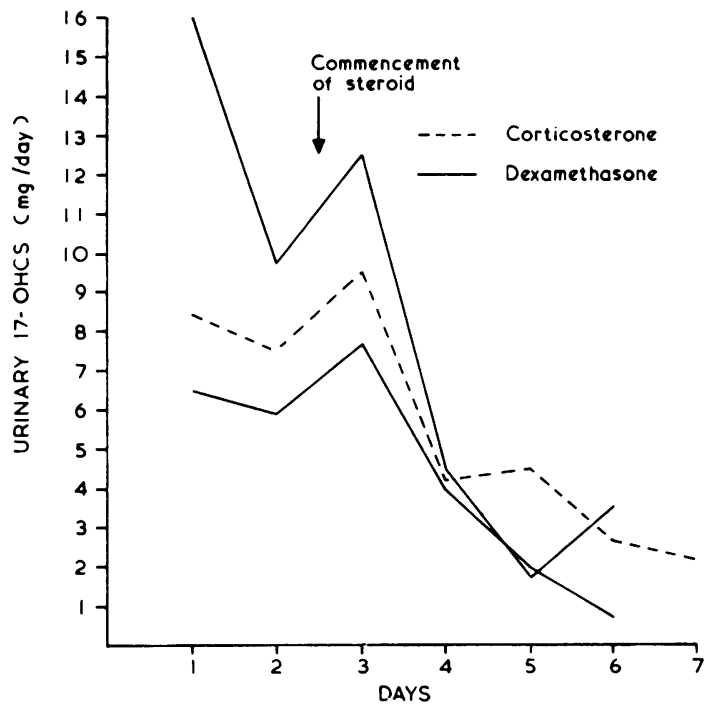

FIG. 4.-The response of urinary 17-OHCS in Case 3 to orally administered corticosterone (100 mg. daily) and dexamethasone

$$
\text { (1.5 mg. daily). }
$$

adrenal activity. Control was obtained with dexamethasone $2 \mathrm{mg}$. daily to which cortisone $50 \mathrm{mg}$. daily was added to maintain adequate sodium retention.

Case 4. This male child was born on October 10, 1962 , and was the third child of healthy unrelated parents.

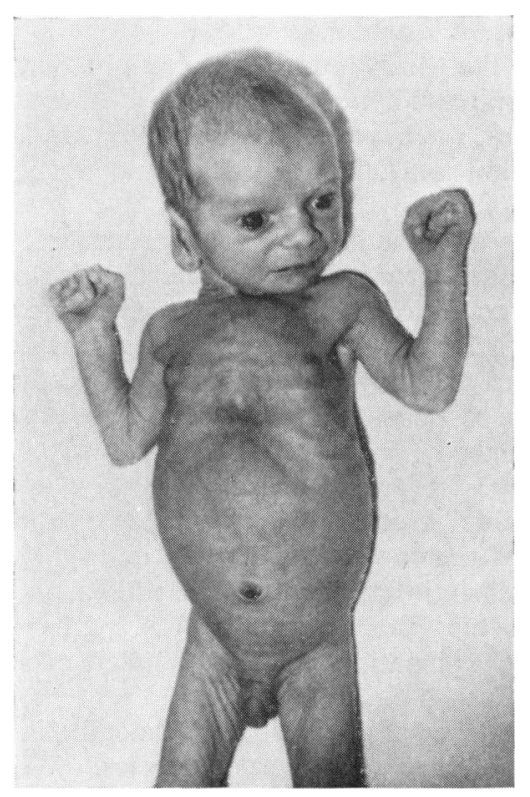

Fig. 5.-Case 4, at birth. Genitalia suggest female virilism, but nuclear sex is male.
The first child, a male, died in another hospital when 1 month old and at autopsy he was found to have congenital adrenal hyperplasia. The genitalia were reported to be normal.

At birth in the Royal Maternity Hospital, Glasgow, he was seen to be cryptorchid, with scroto-labial folds. The urethra opened at the tip of a small hooded phallus (Fig. 5). The serum electrolytes in cord blood and subsequently in venous blood are shown in Table 2 . A tentative diagnosis of female virilism was made but urinary pregnanetriol output during the first three days of life was 48,28 and $49 \mu \mathrm{g}$. per day (these figures are probably normal for a newborn child, although the

TABLE 2

SERUM ELECTROLYTES AND BLOOD UREA IN RELATION TO THERAPY IN CASE 4

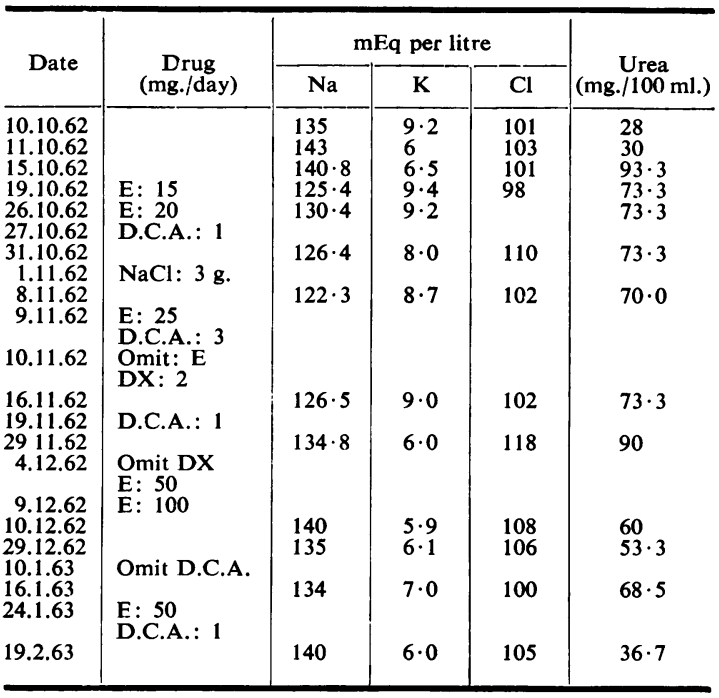

E, cortisone.

DX, dexamethasone.

D.C.A., deoxycorticosterone acetate.

data available for comparison are scant). Block estimations of urinary steroids on the subsequent two days, however, gave the high values expected in congenital adrenal hyperplasia (Table 1). A cystogram outlined a normal bladder, but no other pelvic structure. Cells from the buccal mucosa were chromatin negative on several occasions.

By the ninth day of life there were clinical and biochemical indications of incipient adrenal failure. Cortisone $15 \mathrm{mg}$. daily with $1 \mathrm{~g}$. salt daily were given, but both required to be increased (Table 2) because of a poor initial response. Blood pressure was $90 \mathrm{~mm}$. $\mathrm{Hg}$ (flush technique). D.C.A. $1 \mathrm{mg}$. daily intramuscularly was commenced and later this was varied to suit immediate need (Table 2). At one point cortisone was replaced by dexamethasone, but no advantage was noted. Clinical 
improvement was only obtained when cortisone was increased to $100 \mathrm{mg}$. daily. After a prolonged period at this high level he was discharged from hospital when 14 weeks old. He was then receiving, daily, cortisone $50 \mathrm{mg}$., D.C.A. $1 \mathrm{mg}$. intramuscularly, and salt $3.5 \mathrm{~g}$.

When seen as an out-patient, he had progressed well, and when aged 6 months he weighed $6.46 \mathrm{~kg}$.; blood pressure was $100 \mathrm{~mm}$. $\mathrm{Hg}$ (flush technique).

Meanwhile chromatographic separation of steroids from pretreatment urine was in progress and the results are shown in Table 3. The principal finding was a high excretion of dehydroepiandrosterone (35 $\mu \mathrm{g}$. per day; normal 0-7 $\mu \mathrm{g}$. per day). This indicates at least a partial 3- $\beta$-hydroxysteroid (3- $\beta$-ol) dehydrogenase deficiency.

Summary. A male child, observed from birth till 6 months of age, with congenital hyperplasia of the adrenal cortex. Urinary steroid analyses indicated a partial block in the conversion of pregnenolone to progesterone due to a 3- $\beta$-ol-dehydrogenase deficiency. Clinically there were signs of adrenocortical insufficiency and improvement was achieved only by seemingly excessive doses of cortisone and D.C.A.

TABLE 3

CHROMATOGRAPHY OF URINARY STEROIDS IN CASE 4 (Third day of life)

\begin{tabular}{l|c}
\hline \multicolumn{1}{c|}{ Steroid } & $\mu \mathrm{g} . / \mathrm{day}$ \\
\hline Androsterone & $25 \cdot 7$ \\
Aetiocholanolone & $9 \cdot 91$ \\
Dehydroepiandrosterone & $35 \cdot 0$ (normal $0 \cdot 7 \mu \mathrm{\mu g} . / \mathrm{day}$ ) \\
Tetrahydrocortisone & $347 \cdot 7$ (normal $40-180 \mu \mathrm{g} . / \mathrm{day}$ ) \\
Pregnanetriol & $42 \cdot 0 \quad$ first day of life \\
$\Delta^{5}$-Pregnenediolone & $76 \cdot 2$ \\
\hline
\end{tabular}

\section{Methods for Steroid Analysis}

Since these investigations have been undertaken over the past 11 years, the chemical methods employed and the number of steroid groups estimated have varied. Urinary 17-oxosteroids were determined at first according to Tompsett (1949) and later by a modification of the M.R.C. method (M.R.C. Committee on Clinical Endocrinology, 1951). For urinary 17-hydroxycorticosteroids, 17-oxogenic and 21-deoxyketols the methods of Appleby, Gibson, Norymberski and Stubbs (1955) and Appleby and Norymberski (1955) were used. The ratio $(R)$ of the 11-deoxy to the 11-oxygenated17-oxosteroids derived from the 17-oxogenic steroids was found by the method of Morris (1959). This method estimates pregnanetriol in urine as a 17-oxogenic steroid, the oxidation of pregnanetriol to aetiocholanolone being accomplished by sodium bismuthate. In urines containing excess quantities of pregnanetriolone, 11-oxo-aetiocholanolone will be formed after sodium bismuthate oxidation. A normal $\mathbf{R}$ value in congenital adrenal hyperplasia will only be significant if it is known that pregnanetriolone is not increased.

The Fotherby and Love (1960) procedure for the estimation of urinary pregnanetriol was used, although in certain instances paper chromatographic examination by the Cox (1959) technique showed the presence of some non-specific chromogenic material in the final extract. In such cases the Cox (1959) technique was used to give a specific semiquantitative estimation of pregnanetriol. Urinary oestrogens were estimated by the method of Brown (1955). Fractionation of individual urinary steroids in Case 4 was by the techniques described by Birchall, Cathro, Forsyth and Mitchell (1961).

\section{Discussion}

It is now recognized that congenital adrenal hyperplasia is a genetically determined enzymatic defect in the biosynthesis of hydrocortisone (cortisol). The common defect involves the C-21-hydroxylation of 17- $\alpha$-hydroxyprogesterone. In the hypertensive form of congenital adrenal hyperplasia the defect involves the C-11-hydroxylation of 11-deoxycortisol (Compound S). Recently Bongiovanni (1962) has shown that in some cases the conversion of pregnenolone to progesterone is impaired (Fig. 6). This block, early in the pathway, is due to a deficiency of the enzyme 3- $\beta$-hydroxysteroid dehydrogenase (3- $\beta$-ol-dehydrogenase).

A partial C-21-hydroxylase defect results in the simple virilizing form of the disease, but when the defect is complete, sodium loss is present (Eberlein and Bongiovanni, 1960). The principal sodiumretaining corticosteroids, aldosterone and 11-deoxycorticosterone (DOC), carry a C-21-hydroxyl group. Thus the difference between the simple virilizing type and the sodium-losing type is quantitative rather than qualitative and only one of degree. Earlier, the same authors pointed out that in congenital adrenal hyperplasia due to C-11-hydroxylase deficiency, the hypertension was due to an abnormal production of DOC (Eberlein and Bongiovanni, 1955).

In the absence of 3- $\beta$-ol-dehydrogenase, production of aldosterone, DOC and cortisol is impossible and the condition is probably incompatible with life beyond a few days or weeks. A partial deficiency of the enzyme, however, results in reduced amounts of active corticosteroids, and five of the six cases so far described (Bongiovanni, 1962) have been 'saltlosers'. 3- $\beta$-ol-hydrogenase also plays a part in the gonadal synthesis of testosterone, and a deficiency of the enzyme during the embryonic period could result in incomplete masculinization of the male foetus (Bongiovanni, 1962). This is likely to be the explanation for the incomplete masculinization in Case 4.

The pattern of urinary steroid metabolites differs in each of these enzyme deficiencies. With C-21hydroxylase deficiency, pregnanetriol and 11-oxypregnanetriol (pregnanetriolone) are increased, while 


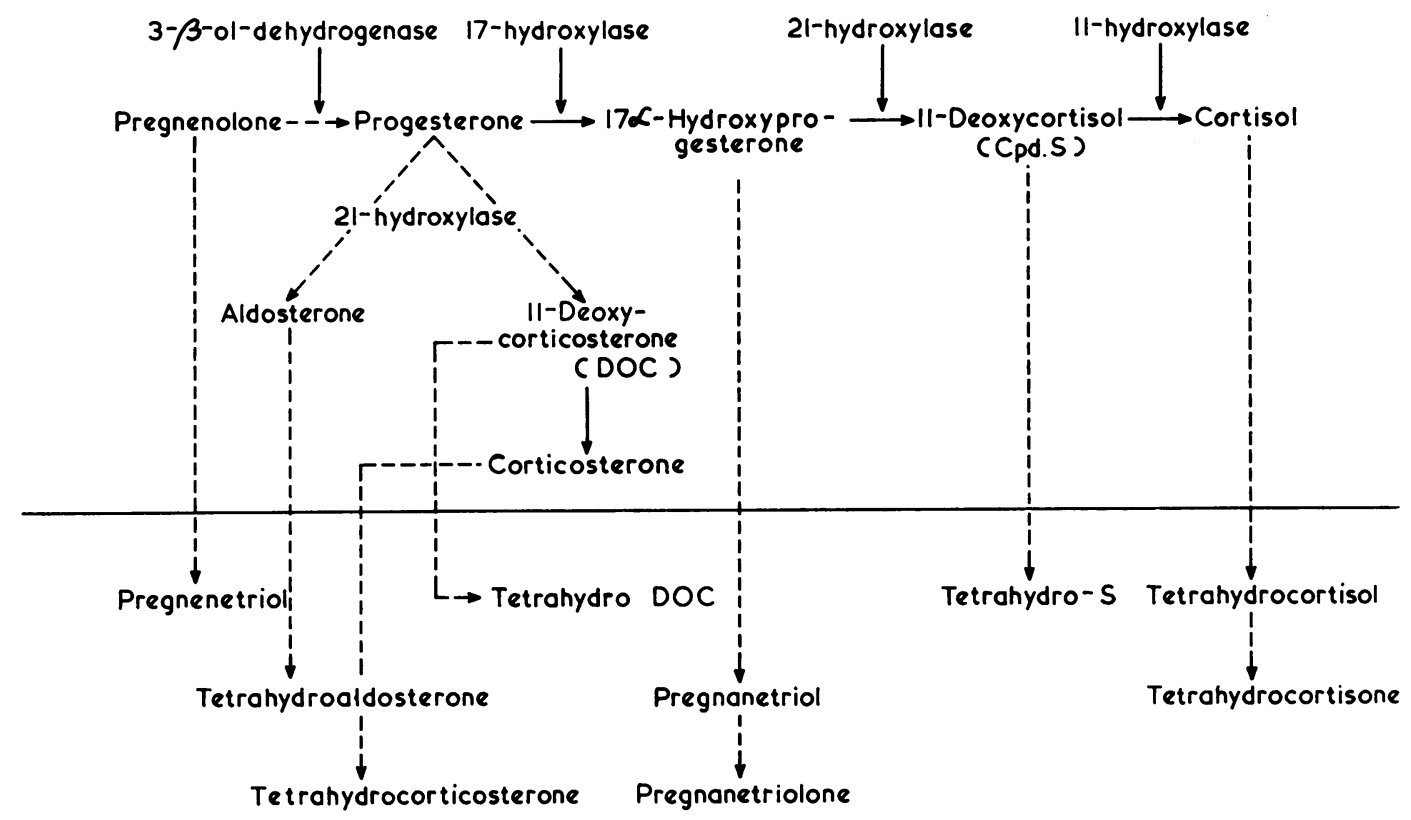

\section{Metabolites}

Fig. 6--Biosynthetic pathway of cortisol indicating the enzymes involved. Pregnanetriolone is the metabolite of 21 -deoxycortisol formed by the 11-hydroxylation of 17- $\alpha$-hydroxyprogesterone. The biosynthesis of aldosterone may be via DOC and corticosterone or by other routes as yet uncertain.

with the C-11-hydroxylase deficiency the metabolites of compound $\mathbf{S}$ and DOC (i.e. tetrahydro-S and tetrahydro-DOC) and pregnanetriol are found but not pregnanetriolone. In 3- $\beta$-ol-dehydrogenase deficiency, metabolites of pregnenolone appear in the urine as well as other substances with the 3- $\beta$-hydroxysteroid $\left(\Delta^{5} 3-\beta\right.$-ol) structure. Included in this group is dehydroepiandrosterone (DHEA), a precursor of testosterone.

Case 1 is an example of partial C-21-hydroxylase deficiency showing virilism as the only clinical feature. Although the clitoris was amputated its growth continued until effective adrenal suppression was achieved with prednisolone.

Case 2 demonstrates the result of a complete C-21-hydroxylase deficiency, namely virilism and salt loss. Originally she required D.C.A. in addition to cortisone, but subsequently did well on prednisolone alone while permitted to take salt freely. At the time of writing she is adequately controlled on 9 - $\alpha$-fluorohydrocortisone $0.45 \mathrm{mg}$. daily and has no further desire for excess salt. The daily excretion of pregnanetriol is also normally low.
Compared with cortisol, $9-\alpha$-fluorohydrocortisone is more active as a glucocorticoid by 10 times and as a mineralocorticoid by 800 times. It thus appears that control of sodium loss is a more important factor in adrenal suppression than replacement of glucocorticosteroids.

In Case 3, the adrenal overactivity was not suppressed by high doses of cortisone. This was evidenced chemically by a continued high urinary excretion of steroid metabolites and clinically by advancing ossification and growth. Green, Cleveland and Wilkins (1961) have observed escape from suppression with cortisone and have attributed this to the transient action of oral cortisone. They report the successful use of triamcinolone (9- $\alpha$-fluoro16- $\alpha$-hydroxyprednisolone) when cortisone had failed. Cox (1962) found that pregnanetriolone disappeared from the urine in congenital adrenal hyperplasia during treatment with cortisone more slowly than pregnanetriol. A normal $\mathbf{R}$ value (Morris, 1959; Hill, 1960) found in congenital adrenal hyperplasia during treatment need not therefore indicate good control. In our case 
cortisone was given four times daily to reduce the tendency to escape, but the urinary pregnanetriol and pregnanetriolone remained comparatively high. Absorption from the gut seemed adequate as indicated by the high urinary 17 -hydroxycorticosteroids during treatment. Good adrenal suppression was achieved with dexamethasone, but since this substance has no mineralocorticoid activity, a small amount of cortisone was included in maintenance therapy to assist in sodium retention.

Case 4 is an example of the salt-losing type of congenital adrenal hyperplasia in a male with cryptorchidism. He was resistant to replacement therapy in 'physiological' doses, . but responded to a much increased dosage of cortisone and D.C.A. Bongiovanni $(1961,1962)$ was the first to report six cases of this new syndrome, five of which were 'salt-losers', and these five died within the first three months of life. Three of the six cases were male with hypospadias, and he suggests that the failure to complete masculine development is in keeping with a deficiency of 3- $\beta$-ol-dehydrogenase. The enzyme is known to have a part in the gonadal biosynthesis of testosterone. The partial nature of the enzyme deficiency in our case is clear since significant quantities of tetrahydrocortisone and normal amounts of pregnanetriol were present in the urine (Table 3).

\section{Summary}

The clinical types of adrenogenital virilism are reviewed.

Four such cases, due to congenital adrenal hyperplasia, are described in detail. The biochemical findings and treatment are outlined.

In discussion, the enzyme deficiencies in the biosynthesis of hydrocortisone, now recognized as the cause of the condition, are considered, and the resultant patterns of urinary steroid metabolites are indicated.

The report includes an example, believed to be the first described in this country, of congenital adrenal hyperplasia due to a deficiency of 3- $\beta$ hydroxysteroid dehydrogenase.

We are grateful to Professor J. H. Hutchison for permission to publish these cases and for his constant help and encouragement. Thanks are also due to Dr.
Beryl Davis for estimating blood corticotrophin, Dr. Eileen $E$. Hill for monitoring the early $R$ values in Case 3, Dr. J. B. Brown for the oestrogen levels in Case 1, and Dr. F. L. Mitchell for chromatographic separation of individual urinary steroids in Case 4. Part of the expense of these investigations was defrayed by the Rankin Funds of the University of Glasgow.

\section{REFERENCES}

Appleby, J. I., Gibson, G., Norymberski, J. K. and Stubbs, R. D. (1955). Indirect analysis of corticosteroids. 1. The determination of 17-hydroxycorticosteroids. Biochem. J., 60, 453.

- and Norymberski, J. K. (1955). Indirect analysis of corticosteroids. 2. The determination and identification of urinary 17-hydroxy-20-oxosteroids unsubstituted at C (21). ibid., $60,460$.

Birchall, K., Cathro, D. M., Forsyth, C. C. and Mitchell, F. L. (1961). Separation and estimation of adrenal steroids in the urine of newborn infants. Lancet, $1,26$.

Bongiovanni, A. M. (1961). Unusual steroid pattern in congenital adrenal hyperplasia: deficiency of $3 \beta$-hydroxy dehydrogenase. J. clin. Endocr., 21, 860.

(1962). The adrenogenital syndrome with deficiency of $3 \beta$ hydroxysteroid dehydrogenase. J. clin. Invest., 41, 2086. and Eberlein, W. R. (1961). Defects in steroidal metabolism of subjects with adrenogenital syndrome. Metabolism, 10,917.

Brown, J. B. (1955). A chemical method for the determination of oestriol, oestrone and oestradiol in human urine. Biochem. J., 60,185 .

Cara, J. and Gardner, L. I. (1960). Two new subvariants of virilizing adrenal hyperplasia. J. Pediat., 57, 461.

Coleman, E. N. and Arneil, G. C. (1958). Adrenocortical pseudohermaphroditism with salt-losing crises. Scot. med. J., 3, 445.

Cox, R. I. (1959). The separation and quantitative estimation of pregnane-3 $\alpha, 17 \alpha, 20 \alpha$-triol, pregnane-3 $\alpha, 17 \alpha, 20 \alpha$-triol-11-one, and other urinary acetaldehydogenic steroids. J. biol. Chem., 234, 1693.

- (1962). Steroid metabolites in congenital adrenal hyperplasia. In The Human Adrenal Cortex, Proc. Conf. held at Glasgow, 1960 ed. A. R. Currie, T. Symington and J. K. Grant, p. 383, Livingsto

Eberlein, W. R. and Bongiovanni, A. M. (1955). Congenital adrenal hyperplasia with hypertension: unusual steroid pattern in blood and urine. J. clin. Endocr., 15, 1531. - (1960). Pathophysiology of congenital adrenal hyperplasia. Metabolism, 9, 326.

Fotherby, K. and Love, D. N. (1960). A modified method for the estimation of pregnanetriol in urine. J. Endocr. 20, 157.

Gardner, L. I. and Migeon, C. J. (1959). Unusual plasma 17-ketosteroid pattern in a boy with congenital adrenal hyperplasia and periodic fever. J. clin. Endocr., 19, 266.

Gonzales, R. F. and Gardner, L. I. (1956). Congenital adrenal hyperplasia with associated episodes resembling histamine poisoning. Pediatrics, 17, 524.

Green, O. C., Cleveland, W. W. and Wilkins, L. (1961). Triamcinolone therapy in the adrenogenital syndrome. ibid., 27, 292.

Hill, E. E. (1960). Adrenocortical Disorders in Children: The Adrenal Cortex. Pitman Medical Publishing Co., London.

M.R.C. Committee on Clinical Endocrinology (1951). Proposed standard method of 17-ketosteroid determination. Lancet,
, 585.

Morris, R. (1959). Pregnanetriol in urine: determination as a 17-ketogenic steroid. Acta endocr. (Kbh.), 32, 596.

Tompsett, S. L. (1949). The determination of the total neutral 17-ketosteroids in urine. J. clin. Path., 2, 126.

White, F. P. and Sutton, L. E. (1951). Adrenogenital syndrome with associated episodes of hypoglycemia. J. clin. Endocr., 11, 1395

Wilkins, L., Crigler, J. F., Jr., Silverman, S. H., Gardner, L. I. and Migeon, C. J. (1952). Further studies on the treatment of congenital adrenal hyperplasia with cortisone. ibid., 12, 1015. , Lewis, R. A., Klein, R. and Rosemberg, E. (1950). The suppression of androgen secretion by cortisone in a case of adrenal hyperplasia; preliminary report. Bull. Johns Hopk. Hosp., 86, 249. 